\title{
Mimari ve Plastik Sanat Akımlarının Gotik ve Rönesans Dönem Koro Müziğine Yansımaları
}

\section{The Reflections of Architectural and Plastic Art Movements to The Gothic and Renaissance Period of Choir Music}

\section{Hasan Açılmış}

Dr. Öğr. Üyesi, Gaziantep Üniversitesi, Türk Musikisi Devlet Konservatuvarı, Ses Eğitimi Bölümü email: acilmis@gantep.edu.tr (DORCID ID: https://orcid.org/0000-0003-4687-7070

\footnotetext{
$\underset{\text { tortuthors sesearchers }}{\text { iThenticate }} \mathrm{Bu}$ makale bilimsel etik ve kurallara uygun hazırlanmış ve intihal incelemesinden geçirilmiştir. Etik kurul onayı gerektirmemektedir.
}

Atıf (APA 6)/To cite this article

Açılmış, H. (2021). Mimari ve plastik sanat akımlarının Gotik ve Rönesans dönem koro müziğine yansımaları. Atatürk Üniversitesi Güzel Sanatlar Enstitüsü Dergisi, 27(46), 191-200. https://doi.org/10.35247/ataunigsed.818517

Makale Gönderim Tarihi/Received: 30/10/2020

Makale Kabul Tarihi/Accepted: 17/02/2021

Makale Yayın Tarihi/Published: 29/03/2021

Review Article/Derleme Makale

\section{Öz}

Bu araștırmada insanlık tarihinin en karanlık dönemi olarak kabul edilen Orta Çă̆ boyunca din baskısı altında gelişen mimari ve plastik sanat akımlarının özellikle Gotik sanatına ve ardından gelen Rönesans dönemine etkileri incelenmiş, bunların paralelinde gelişen koro müziğine yansımaları örneklerle açıklanmıștır.

Araștırmada 4. yüzyıldan itibaren Hristiyanlık inancının toplum üzerindeki etkisini daha da kalıcı hale dönüştürmek için yapılmış kilise binaları, heykeller, freskler ve resimlerin özellikleri yanında değișen ve gelişen tekniklerine de yer verilmiștir. Bu bağlamda mimari eserlerin iç ve dış yapısındaki fiziksel özellikler açıklanmıș, heykellerin bina dıșlarındaki heykel formlarının ilerleyen zamanlarda kilise yapılarından ayrılıp tek başlarına heybetli yapılara dönüșmesiyle gözlenen görsel farklılıklar yorumlanmıștır. Fresk ve resimlerde konu edilen temaların renk, 1şık, fon ve perspektif açısından teknik farklılıkları Gotik ve Rönesans dönemlerinin özellikleri dikkate alınarak ifade edilmiştir.

İnsanlık üzerinde dini inanışları kullanarak bir egemenlik kurmayı amaçlayan Orta çă Hristiyanlık inancı, mimaride ve plastik sanatlarda olduğu kadar müzikte de etkisini göstermiștir. Bu egemenlik kurma ihtiyacı o kadar fazladır ki müzikle ifade edilen duygular bașlangıcta hep kutsal kitapta anlatılanlarla sınırlı kalmıştır. Bu baskıya rağmen ilerleyen zamanlarda insanlık özgürce düsünmesini engelleyen yasakları hafifletmenin bir yolunu bulmaya çalıșmıș, kendini ifade etmek için çeșitli yollar aramıştır.

Orta çağ boyunca ruhsal olanı büyüten ve insani olanı göz ardı eden Hıristiyanlık inancı bu anlayısııı mimari ve plastik sanatlara yansıttığı gibi müzik sanatına da yansıtmıştır. Rönesans'la birlikte tüm bu gelișmeler ıșığında dönemin müzik sanatı, başlangıçta sade bir ezgi yapısına sahipken sonraları giderek birbirinden bağımsız hareket edebilen bağımsız bir yapıya bürünmüştür. Özellikle koro müziğinde bestecilerin her biri kendi adıyla özgün işler yapabilme hürriyetini kazandıkça kendi düşüncesini yaptığı eserlere de yansitmıștır.

Anahtar Kelimeler: Gotik, Rönesans, Mimari, Plastik Sanatlar, Koro Müziği

\begin{abstract}
In this research, the effects of architectural and plastic art movements especially to Gothic art and the subsequent Renaissance period that developed under the pressure of religion during the Middle Age, which is accepted as the darkest period of human history, and their reflections on the choral music at the same age are explained with examples.

In the research, the characteristics and developing techniques of church buildings, sculptures, frescoes, and paintings that aimed to make the Christian faith's impact on society more permanent from the 4th century onwards are also included. In this context, the physical properties of the interior and exterior structures of the architectural works and the visual differences observed after the sculptural forms outside the buildings were separated from the church buildings and transformed into majestic structures by themselves are explained. Technical differences of the themes in the fresco and paintings concerning color, light, background, and perspective are expressed by considering the features of the Gothic and Renaissance periods.
\end{abstract}

Aiming to establish sovereignty by using religious beliefs on humanity, the Medieval Christianity belief has shown its influence in music, architecture, and plastic arts. The need to develop this sovereignty is so high that emotions expressed in music have always been limited to those described in the Bible. Despite this pressure, in the future, humanity tried to find a way to alleviate the prohibitions that prevented it from thinking freely and sought various ways to express itself.

The Christian belief, which enlarged the spiritual and ignored the humane throughout the Middle Ages, reflected this understanding of the art of music as well as on architectural and plastic arts. In light of all these developments with the Renaissance, the musical art of the period, while initially having a simple melody structure, later took on an independent structure that could move independently. Especially in choral music, as each of the composers gained the freedom to perform original works under their name, they reflected their thoughts on their products.

Keywords: Gothic, Renaissance, Architecture, Plastic Arts, Choral Music

\section{Giriș}

İnsan, bu dünyada var olduğu ilk andan itibaren kendini yazıyla, müzikle veya resimle ifade etmiştir. İçinde bulunduğu toplumun kurallarını ve inandığı dinin öğretilerini de göz önünde bulundurarak kendini tanımlama ve bu dünyadaki yerini sorgulama ihtiyacı duymuștur. Dolayısıyla hayata dair tüm duygu ve düşüncelerini görsel veya işitsel nesne veya olgularla ifade etmesinden daha doğal bir şey olamaz. "İlk insanlar gök gürültüsünde doğa 
üstü güçlerin simgesini, fırtınanın uğultusunda kötü ruhların sesini, denizin sakin görüntüsünde ya da patlamasında tanrıların iyiliğini ya da öfkesini buluyorlardı. Yankı bir çeşit kehanet, vahşi hayvan sesleri bilinmeyenin habercisi olarak algilaniyordu" (Selanik, 1996, s. 3).

Orta Çağda, Hristiyanlaştırma hareketleri kapsamında inşa edilen ibadet yerleri sanatsal ifadenin hayat bulduğu kesişim noktaları haline gelmiştir. Bu alanlar dini buluşma noktalarıdır ve dini inancın pekişmesine yönelik görsel ve işitsel ifadelerle donatılmıştır. Zaman ilerledikçe özgür düşünceye kavuşan insanoğlu bu mekânsal kısıtlamayı aşarak düşüncesini her yerde ifade etme iradesine sahip olacaktır. Tedavisi olmayan salgın hastalıklar, açlık, savaş, esaret ve Tanrı korkusuyla çevrili bin yıl boyunca insanlık nefes almaya, özgürce fikrini söylemeye ve inancını sorgulamaya çekinmiş, kendisi için doğru olanı sorgulamadan kabul edip uygulamıştır. "İlk çağ filozoflarının aksine orta çağ düşünürleri mutluluğa erişmek için insanın kendi gücüne ve aklına değil tanrının merhameti ve hoş görüsüne ihtiyaçları olduğunu benimsemişlerdir. Orta çağda insandan beklenilen, aklını kullanarak kavramlar üzerinde felsefe aracılığıyla tartışmak yerine inanıp iman etmektir” (Özel, 2014, s. 128). Yaşam ve ölümle ilgili felsefi düşünceler geliştirmek yerine öbür dünya için hazırlık yapmak ve iyi bir dindar olmak insanlık için tek çıkar yolmuş gibi algılanmıştır çünkü “mutluluk bu dünyada değil diğer dünyadadır” (Elmalı ve Özdem, 2013, s. 232). Toplum skolastik felsefenin hâkim olduğu bir zamanda insanlık adına iyiye ve doğruya hizmet edecek bir adım atmaktan uzaklaşmıştır. "Tamamen dinsel niteliğe sahip olan skolastik felsefede evren, insan veya doğayla ilgili yeni bir bilgi ya da düşünce üretme kaygısı taşımaz" (Tufan, 2004, s. 2). Yapılan tüm davranışlar, işler ve düşünceler bu doğrultuda oluşturulmaktadır. "Amaç her şeyi yaratan tanrı vasitasıla varlığın özü nedir? sorusunu yanıtlamaktır” (Çüçen, 2013, s. 28). Dönemin başından itibaren Hristiyanlık inancının putperestlik karşısındaki hareket alanını genişletmek için din adamları büyük bir görev üstlenmişlerdir. "Avrupa'nın kültür, sanat, düşünce, hukuk ve siyaset yapısının Bizans kültürünce belirlendiği dördüncü yüzyılda Aziz Augustinus önderliğindeki Patristik düşünce temel düşünme biçimi haline gelmiştir” (Kalın, 2019, s. 130). "Ona göre tanrının içinde insan, insan ruhunda da tanrı vardır. İnsanın bunu anlayabilmesi için kendini tanıması, anlamak için inanıyorum düşüncesini kabul etmesi gerekir" (Elmalı \& Özdem, 2013, s. 239). Yani bir bakıma içindeki tanrı inancına ulaşabilmek için kendini soyutlayıp tanrıyı bulması, bu bilgiye ulaşması gerekir. Çünkü "değişmeyen tek hakikati bilmek için insanın içindeki tanrı bilgisine ihtiyaç vardır” (Çüçen, 2013, s. 214).

Tarih öncesinden, antik döneme, orta çağdan çağdaş sanat akımlarının ilk kez hayat bulduğu zamanlara kadar farklı bakış açılarıyla geliştirilmiş mimari ve plastik sanat akımlarının koro müziğine etkileri olduğu düşünülerek hazırlanan bu çalışmada mimari ve plastik sanat akımlarının, Gotik ve Rönesans döneminde bestelenmiş koro müziğine yansımaları araştırmanın temel konusunu oluşturmaktadır. Araştırmada insanlık tarihinin en karanlık dönemi olarak kabul edilen Orta Çağ boyunca din baskısı altında gelişen mimari ve plastik sanat akımlarının özellikle Gotik sanatına ve ardından gelen Rönesans dönemine etkileri incelenmiş, bunların paralelinde Hristiyanlık inancını yaymak ve ibadetleri destekleyici bir unsur olarak kullanmak amacıyla geliştirilen, sonraları giderek dünyevi ihtiyaçları ve düşünceleri yansıtmak için seslendirilen koro müziğine yansımaları ve etkileri örneklerle açıklanmıştır.

\section{Yöntem}

$\mathrm{Bu}$ araştırma nitel bir çalışmadır. Verilerin toplanmasında doküman incelemesi yapılmıştır. "Doküman incelemesi, araştırılması hedeflenen olgu veya olgular hakkında bilgi içeren yazılı materyallerin analizini kapsar" (Yıldırım ve Şimşek, 2013, s. 217).

\section{Bulgular ve Yorum}

\subsection{Gotik sanat}

“Gotlara değin” anlamına gelen Gotik kelimesi Avrupa'da 12. yüzyıldan itibaren gelişen sanat yaklaşımını açıklamak için kullanılır. Bu sanatta katedrallerin göğe doğru sivrilen formlarına ek olarak yağmur sularını binadan uzağa püskürtmek gibi mimari işlevleri bulunan canavar görünümlü heykel yapılar (Gargoyle) da dikkati çeker" (Tufan, 2004, s. 11-26). Gotik sanat yapıları, içindeki ve dışındaki görsel detaylarıyla hizmet ettiği amaca yani Hristiyanlık ibadetini pekiştirmeye yönelik görsel formlarla donatılmıştır. "Üç yüz yıl boyunca olgunlaşan ve Romanesk mimarinin tersine dini hakimiyeti, teolojik tutarlılığı mimari stiline yansıtan bu sanat biçimi insanın yaşantısı için değil tanrısal otoriteyi yansıtmak için kullanılmıştır” (Kutlu Altan, 2015, s. 13). Bu otorite öyle büyük ve baskındır ki insanoğlu bu baskı altında geliştirdiği duygularını fiziksel olarak ifade etmek ister ve ortaya çok büyük hacimli mimari yapılar çıkar. Bu büyük oluşum karşısında acizlik duygusunu tadan her birey hipnotize olmuşçasına koşulsuz bir kabullenme yaşar. Tam da bu duygular 1şığında, her an ölümü ve öbür dünyayı hatırlatırcasına ibadet yerlerinde konu edilen resim, heykel ve benzeri sanatsal yorumlamalar çoğalır. Başlangıçta yalnız din konusu işlenirken sonraları ölümler ve ölümlü insanlar da çalışmalara dahil edilmiştir. Gotik sanat anlayışında Gargoyle ve Kimera isimli mimari formlar en önemli heykel türleri olarak kabul edilmiştir" (Nabiyeva, 2017, s. iv). 
"Gotik dönem vitraylarında oymalar ve matematiksel süslemeler önemlidir. Katolik öğretiden sahneler yorumlanır. Işığın dolaysız algılanmasının önüne geçilir. Bu yalın olmayan ışık özgür gibi algılansa da aslında tutsak bir üst anlam içermektedir" (Kutlu Altan, 2015, s. 78). Bu tür ıșık oyunları mimari yapının diğer görsel kurgularıyla birleşince inananlar üzerinde doğrudan bir etki yaratır. "Orta çağda okuma yazmayı bilmeyen halka Hristiyanlık inancını anlatmak ve öteki dünyayla bağlarını daha da güçlendirmek için freskler kullanılmıştır" (Turan, 2011, s. 8). Freskler insan aklını her an ibadet etmesi gerektiği düşüncesiyle sarmalamıştır.

İnsanlık üzerinde dini inanışları kullanarak bir egemenlik kurmayı amaçlayan Orta çağ Hristiyanlık inancı, mimaride ve plastik sanatlarda olduğu kadar müzikte de etkisini göstermiştir. Bu egemenlik kurma ihtiyacı o kadar fazladır ki müzikle ifade edilen duygular başlangıçta hep kutsal kitapta anlatılanlarla sınırlı kalmıştır. Bu baskıya rağmen ilerleyen zamanlarda insanlık özgürce düşünmesini engelleyen yasakları hafifletmenin bir yolunu bulmaya çalışmış, kendini ifade etmek için çeşitli yollar aramıştır.

“Konstantin Roma'nın resmi dini olarak Hristiyanlığ t tanıyınca ayinlerin dili Yunanca' dan Latince’ye geçmiştir... Aziz Ambroisus Bizans’tan Milano’ya giderek ezgileri derlemiş ve halk ezgilerini dinsel içerikli sözlerle birleștirmiștir" (İlyasoğlu , 1995, s. 10). Halk ezgilerinden yararlanarak bir tür ibadet müziği oluşturmak istemesindeki amaç insanların bu ibadet biçimini benimsemesini kolaylaştırmaktır. "Ayinlerde seslendirilen ezgilerin düzenlenmesi, Papa 1. Gregorius'a aittir. Bunlar erkekler tarafından seslendirilen, tek sesli, çalgı eşliği içermeyen, en fazla bir oktav genişliğinde, sakin karakterdeki ezgilerdir. Her hecenin bir ya da iki notayla seslendirildiği hecesel (syllabic) ve tek heceyle seslendirilen süslemeli (melismatic) çeşidi de bulunmaktadır" (Boran ve Şenürkmez, 2015, s. 18).

\section{Görsel 1}

Hecesel (Syllabic) Gregorian Şarkısl, "The Play of The Three Kings"

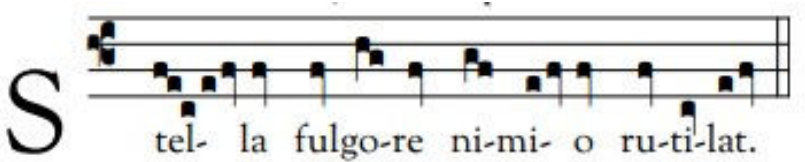

(Anonim, t.y.).

Görsel 2

Süslemeli (Melismatic) Gregorian Şarkısı, "Volsvi, Persidstii Tsarie”"

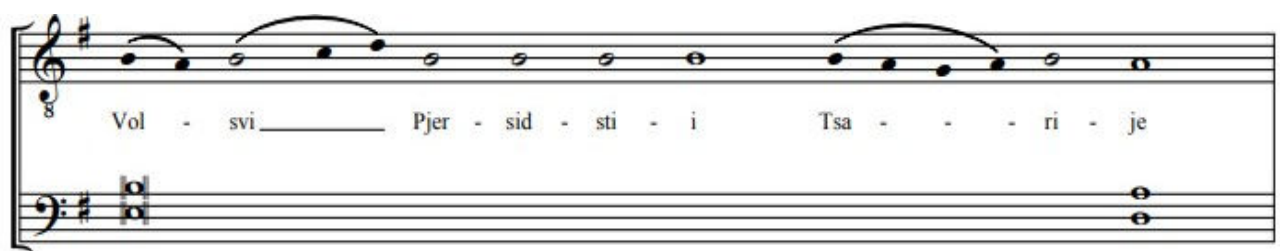

(Anonim, t.y.).

"Aynı dönemde Conductus isimli, tek söz ve tek tür ritmik yapıyla seslendirilen eserler de bulunmaktadır. İki, üç veya dört sesli olabilen bu eserler Latince dilinde söylenen bir bas ses üzerine özgür bir ezginin seslendirilmesiyle oluşurlar" (Sachs, 1965, s. 65).

Görsel 3

Conductus Ezgisi, "Christi Nutu Sublimato”

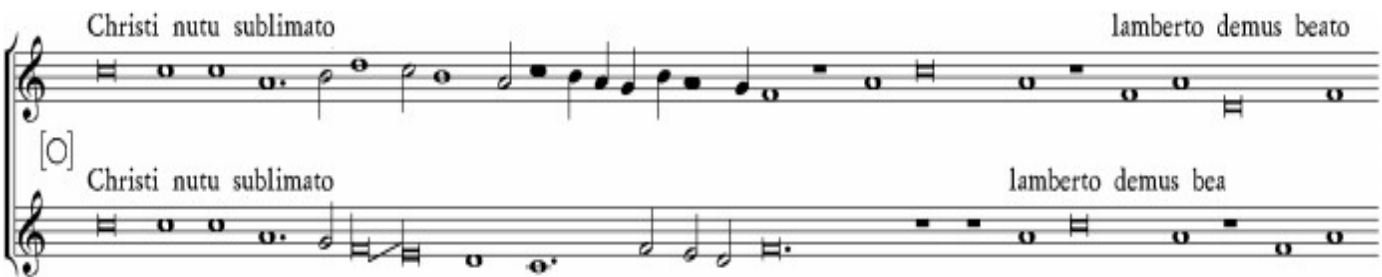

(Brassart, 1445).

"Daha sonraları bu yapıya değişik ritimler eklenerek Organum oluşturulmuştur. Benedictine rahipleri Hucbald ve Prüm Organum kelimesini aynı anda tınlayan iki farklı sesin uyumu olarak tanımlamışlardır" (Boran \& Şenürkmez, 2015, s. 30). 


\section{Görsel 4}

Organum Ezgisi, “Alleluia: Nativitas”

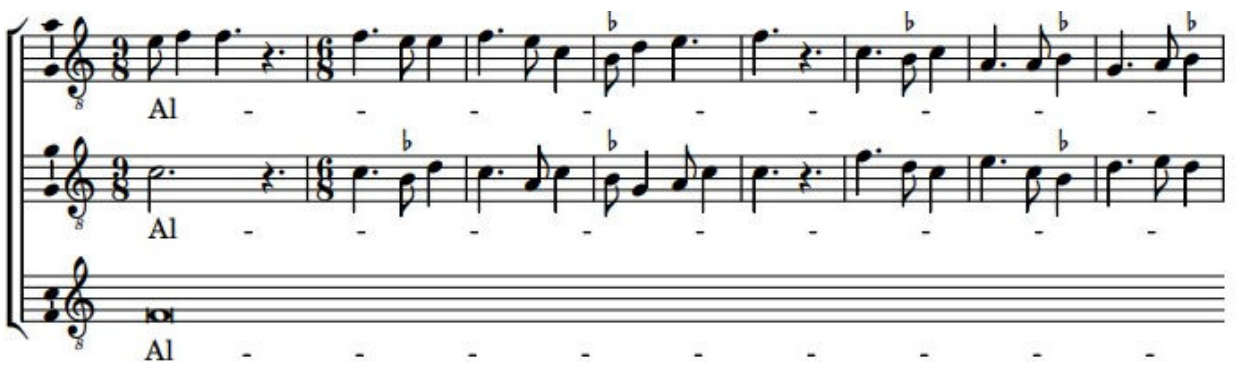

(Pérotin, t.y.).

Tüm bu süreç boyunca müziğin ifade edilmesi için kullanılan semboller aslında günümüzden biraz farklıdır. Daha da doğrusu günümüzde kullanılan nota yazım sisteminin atasıdır. "İlk örnekleri 1250 yılından itibaren görülmeye başlanan ve Köln'lü Franco tarafından hazırlanan Ölçülü Şarkı Sanatı (Ars Cantus Mensurabilis) başlıklı teori kitabında açıklanan şekliyle, müzikal eserlerde seslendirilen notaların süre değerlerinin gösterildiği Mensural Notasyon Tekniği ile yazılmış eserler 1600 yılına kadar görülebilmektedir” (Apel, 1950, s. 439). "Daha sonraları Pierre de la Croix brevis notasını daha küçük süre değerlerine bölerek besteciliğe yeni bir bakış açısı getirmiştir. Philippe de Vitry üçerli bölünme anlayışına (perfekt) bir alternatif olan ikişerli bölünme (imperfekt) yöntemiyle yazdığı yeni eserlerle bu bakış açısını pekiştirmiştir” (Say, 2012, s. 91).

“Avrupa'da 9. yüzyıldan itibaren birbiri ardınca ortaya çıkan ve ilk örnekleri Organum türünde hazırlanan farklı müzikal yapılardan birisi de Motettir" (Atalay, 2015). "Hem eşlikli hem de eşliksiz söylenmek üzere yazılmış örnekleri bulunan bu türün dini sözlerle seslendirilen örnekleri olduğu kadar dinsel olmayan sözlerden oluşturulmuş örnekleri de bulunmaktadır” (Sözer, 1986, s. 509). “Sözlerin de ritimlerin de özgürce değiştirildiği daha serbest bir yapı olan Motet türü eserlerde, en alt ses partisindeki değişmez Gregoryen ezgisi sabit kalmak üzere üst iki ses partisi her besteci tarafından farklı yorumlanabilmiş, kilise çekiminden uzaklaştıkça bu sabit Gregoryen ezgisi (Cantus Firmus) çalgı eşliğine dönüşmüştür” (Boran \& Şenürkmez, 2015, s. 36).

Görsel 5

Motet, "A Nostri Preghi”"

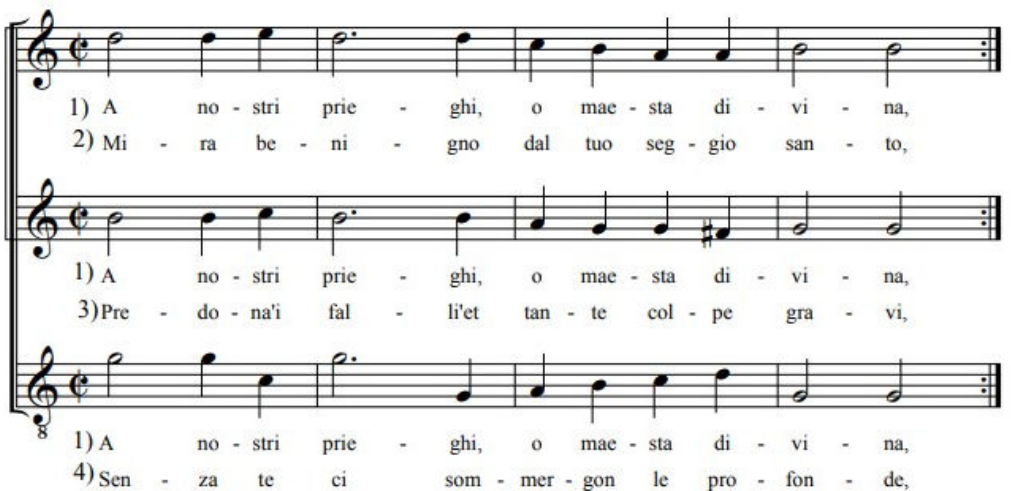

(Animuccia, 1583).

"Leonin, Perotin ve Adam de la Halle'in öncülügüünde gelişen ve ilk Notre Dame ekolü olarak bilinen eski sanat (Ars Antique) akımı Kanon isimli, aynı ezginin ardışık olarak birbirini gölge gibi takip ettiği formda eserler yaratmıştır." (Selanik, 1996, s. 52). "Notre Dame ekolü çoksesliliğe geçişi temsil eder. 12. yüzyıldan itibaren ileri bestecilik çalışmalarının sürdürüldüğü ve usta-çırak ilişkisinin yeni kuşakların eğitimine büyük bir ivme kazandırdığ1 yaklaşık 150 yıllık süre boyunca müzik tarihinin kayda değer gelişmeleri gözlemlenmiştir” (Say, 2002, s. 379). "Yasa ya da kural anlamına gelen ve ana ezgi dışında kalan diğer ezgilerin nasıl olacağına dair talimatları içeren bu metin kendine özgü bir besteleme tekniğine sahiptir” (Boran \& Şenürkmez, 2015, s. 60). 


\section{Görsel 6}

Kanon, "Cosi Pensoso"
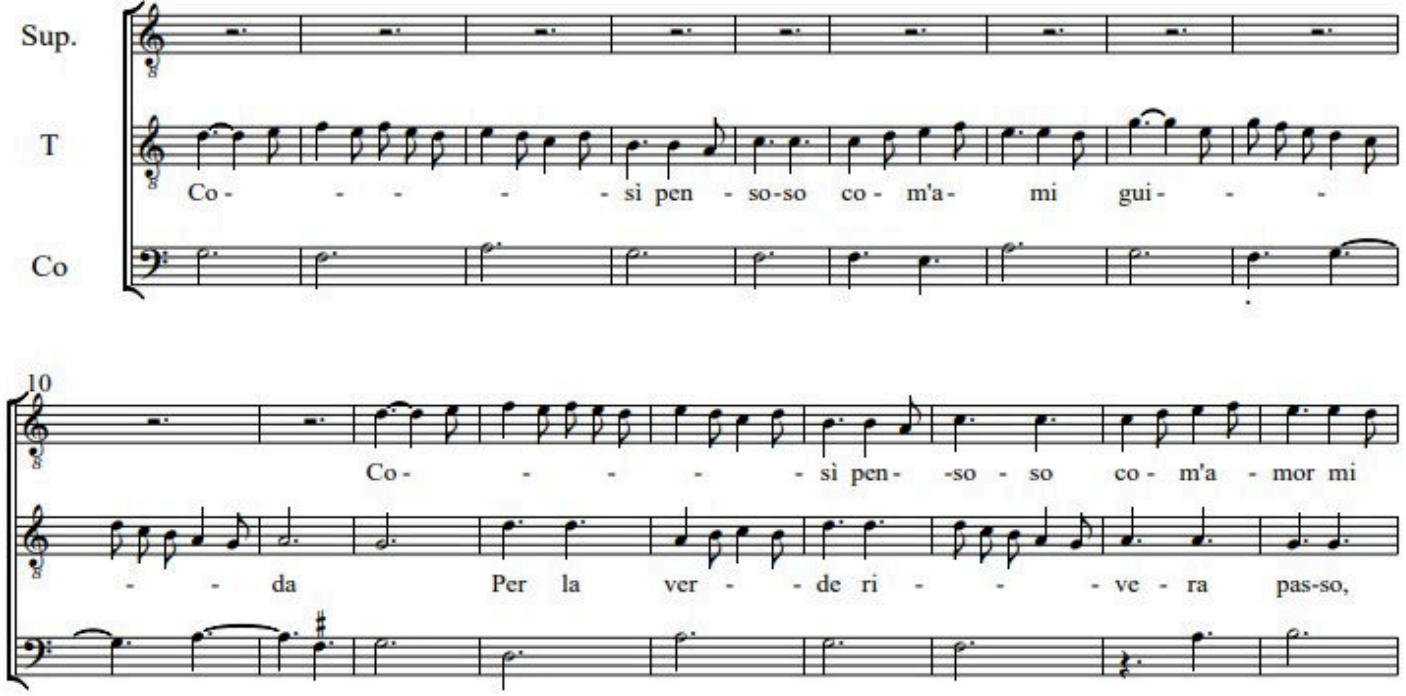

(Landini, t.y.a).

Ars Nova (yeni sanat) isimli kitabında gelenekten kopulmasını öneren Philippe de Vitry, din dişı müziği kilise ile buluşturmuş ve ritmik kilise modlarının yerine geçecek bir yapıyla adını duyurmuştur. Guillaume de Machaut ise Ballade, Rondeau ve Motet gibi din diş1 eserlerle armoninin habercisi kabul edilen Missa türünde dini eserler bestelemiştir. Ars Nova etkisindeki yeni sanatsal eserler, hareketli ritimleri ve bol süslemeleri ile çağın meşhur mimari eseri Notre Dame Katedralinin yapısal özellikleriyle örtüşmektedir (Selanik, 1996, s. 52).

\section{Görsel 7}

Missa, "Messe de Notre Dame"

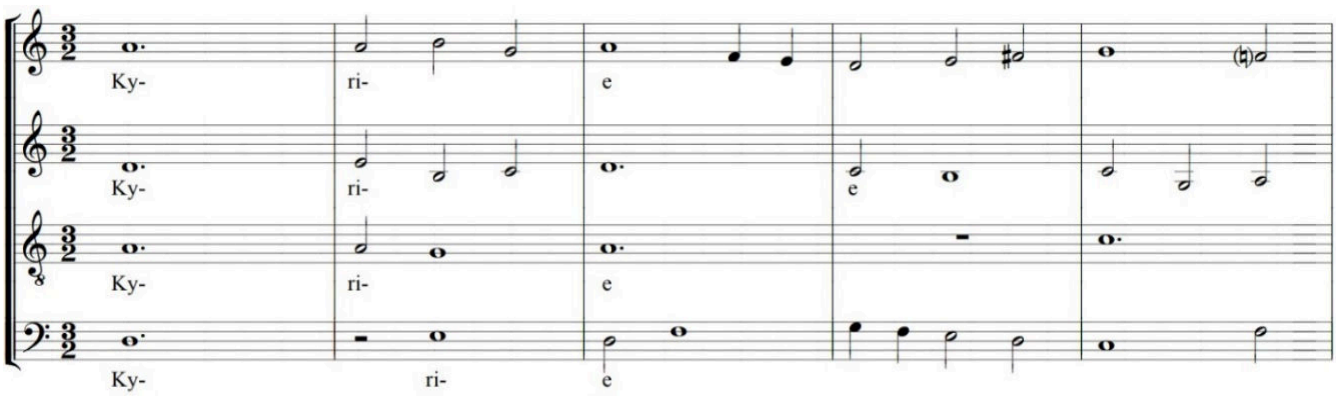

(de Machaut, 1365).

\subsection{Rönesans}

"Yeniden doğuş anlamına gelen ve demokratik ortamı başka toplumsal ilişkiler düzleminde yeniden oluşturmak için bağnazlaşıp totaliterleşmiş kilise yöneticilerine karşı insancıl olanı alternatif olarak sunan Rönesans, iyiyi ve kötüyü bu dünyada arayan, bunun için de bin yıllık Roma hakimiyetini atlayıp Yunan kültürünü kendisine örnek alan bir dönemdir" (Turgut, 2012, s. 51). Koca bir Orta Çağı sanki yokmuşçasına ve bir çırpıda göz ardı etmek, bu karanlık dönem sanki hiç yaşanmamış gibi kabul etmektir. İnsanlık, baskıcı din adamlarına karşı nihayet kendini ifade etme firsatını bulmuşken, düşüncesine daha yakın bulduğu Yunan kültürünü benimsemesi çok da zor olmamıştır. "Rönesans ile oluşan yenilenme çabası antik çağın hümanist düşüncesini merkeze alarak güzel sanatlarda hayat bulmuştur. İnsana olan ilgi, yaşam, tanrı ve diğer her şey hakkında yorum yapabilmek için kendi aklını kullanmak düşüncesi ağır basmaktadır” (Krausse, 2005, s. 9). Hümanist düşünceyi daha çok benimsedikçe kendini, benliğini tanımaya daha fazla zaman bulan insanoğlu, kendi gibi düşünenleri aramış ve onlarla sosyal bir bağ kurmuştur. "Kendi gücünü tanıyan, kendisine güvenen, dünyasal güzelliklerin farkına varan, yaşama sevinciyle dolu, geçmişiyle bağ kurup geleceği de yaratabilme kabiliyetine sahip olduğunu düşünen bir insan doğmuştur artık” (Cubberley, 2004, s. 256). Aklın ve felsefenin 1şı̆̆ında dış dünyayla iletişimini pekiştirdikçe, kendi bedeniyle barışmaktadır.

"Kilisenin dışına taşan bilgi ve düşünce doğrultusunda yaşamın sorgulanması gündeme gelmiştir" (Şenyapıll, 2004, s. 22). "Bu değişim edebiyatta da kendine yer bulmuş, Dante'nin İlahi Komdesya's1, Boccaccio'nun 
Decameron'u ve Petrarca'nın şiirleri gibi konuşulan dilde yazılan edebi metinler sayesinde bir aydınlanma hareketi doğmuştur” (Boran \& Şenürkmez, 2015, s. 39). Bu hareketten aldığ güçle insan birey olarak değerli bir varlık olduğunun farkına varmıştır. "Orta çağda tanrısal düzenin basit bir unsuru olarak görülen insanın ve bu dünyadan öteki dünyaya geçişin kapısı olarak görülen ölümün yerine, insana ve insani olana artan ilgi Rönesans’ta kendini göstermiştir" (Buchholz, 2005, s. 12).

“14. yüzyılın başlarında ressamlar perspektif kurallarını geliştirmişlerdir. Sanat denince akla yalnız dinsel temalar gelirken insanın yaşadığı dünyayla ilgilenmeye başlamasıyla yeni temalar oluşmaya başlamıştır. Artık ressamlar zanaatkar değil, birer sanatçıdır" (Krausse, 2005, s. 6). Her biri kendi adıyla özgün işler yapabilme hürriyetini kazandıkça kendi doğrusunu yaptığı eserlere de yansıtmıştır. "Uygulamaya verilen öneme karşı çıkıp sanatsal özgürlüğü savunan Leonardo da Vinci ve Michelangelo da sanat akademilerini kurmuş ve kuramsal eğitimleri bu akademilerde vermenin doğru olacağını savunmuşlardır" (Öndin, 2016, s. 60). Bu demektir ki, teknik çalışmanın önemi her zamankinden daha fazla ön plandadır. "Geometri, perspektif ve anatomi derslerine ek olarak canlı model ve maket çizimleri yapılarak sanatsal idealler gerçekleştirilmek istenmiștir” (Öndin, 2016, s. 60). "14. yüzyıldan itibaren nesnelerin kendileri yerine anlamlarının resmedilmesi sona ermiş, nesneler üç boyutlu gerçek mekanlarda resmedilmeye başlamıştır. Giotto, mimari çevre ile figürler ve onların dizilimini gerçek mekanlarda resmederek figürlerle arka plandakiler arasında mekânsal bir boşluk yaratmayı başarmış, resimler derinlik kazanmıştır" (Akyürek, 1994, s. 103-105). "Hans Holbein dönemin tüm gelişmelerini aktarmak istermişçesine Sefirler isimli tablosunda kompozisyonun tam ortasındaki masada bazı nesneleri ön plana çıkartmıștır. Dilbilgisi, mantık, retorik, aritmetik, müzik, geometri ve astronomi bu tablodaki nesneler ve nesnelerin iki yanında ayakta poz veren kişiler üzerinden anlatılmaktadır" (Brotton, 2012, s. 10). "Mimaride ağırbaşlılık ve denge esas alınmış ve yapılar tamamen insani ve dünyevi bir hale dönüştürülmüştür. Denge üzerine kurulan bu dönem mimari yapılarında merkezden bakıldığında sağ ve sol taraflarda aynı yapısal özellikler bulunur. Rönesans mimarisi Antik Yunandan bu yana yapılmış en büyük kubbeyi, Duomo Frenze'yi inşa etmiştir" (Çakır, 2012, s. 49). "Rönesans heykelinin en önemli örneği Erosmo de Narni' de olduğu gibi anatomik olarak insanın görüntüsünün yansıtılmasında adeta antik Roma'nın devamı kabul edilebilecek çalışmalar karşımıza çıkmıştır” (Akyürek, 1994, s. 142). "Rönesans’ta duyguları yansıtan insan tasvirleri gelişir. Kurgu, oran, ölçü, simetri, derinlik ve hacim kavramları form anlayışını oluşturur. Eserler daha çok portre, mitoloji ve din temalıdır. Işık ve gölge arasındaki geçişler dikkati çeker. Resim sosyal statünün yansımasıdır. Cübbe, sütun, perde, taç, asa, kılıç gibi nesneler toplumdaki statüyü ifade ederler" (Tüzün, 2004, s. 38).

“Özgürleşen düşünce yapısı, Martin Luther'in manifestosunda kendini belli eder. Kilise insanla tanrı arasında aracı olmalıdır. Papanın insan üstü bir varlıkmış gibi tanıtılması yanlıştır. Herkes kendi dilinde ibadet edebilmelidir. Kilisenin anlattığından farklı bir din olduğu fark edilince Protestanlık adı altında yeni bir mezhep oluşturulur" (Tüzün, 2004, s. 36). Bu değişim güzel sanatların her dalında olduğu kadar müzikte de kendisine yer bulmuştur. İnsanlar bu protestoyu sadece ibadetlerinde değil müzikte de yaşatmış, düşündüğü dilde şarkı söyleme özgürlüğünü sonuna kadar kullanmıştır. Seslendirilen eserler çağın teknik getirisi sayesinde o anla sınırlı kalmamış, sonraki zamanlara da taşınmıştır. Bunun için gerekli olan, ezginin yazıya dökülmesi yani kâğıda basılmasıdır. "Katolik ayinlerde Latince metin okunurken bu başkaldırı ile metinler Almancaya çevrilir. Farklı ülkelerde Koral, Psalm veya Anthem olarak isimlendirilen yeni bir ilahi müzik biçimi oluşmuştur. Çoksesli eserlerin kutsal sözler içerebileceğini göstermek için Giovanni Palestrina altı sesli Missa besteler" (İlyasoğlu , 1995, s. 18). Yeni formlarla bestelenen çoksesli yapıdaki koro eserlerinde ilahi içerikli sözler kullanılmış ve toplumun bu yeni şarkı söyleme şekliyle tanışması sağlanmıştır. "Toplamda elli dokuz ciltlik çalgı ve ses müziği notasının baskısını yapan Ottaviano Petrucci sayesinde bestelenen müzikler geniş kitlelere ulaşmaya başlamıştır” (Boran \& Şenürkmez, 2015, s. 59).

\section{Görsel 8}

Psalm, "Psalm 11"

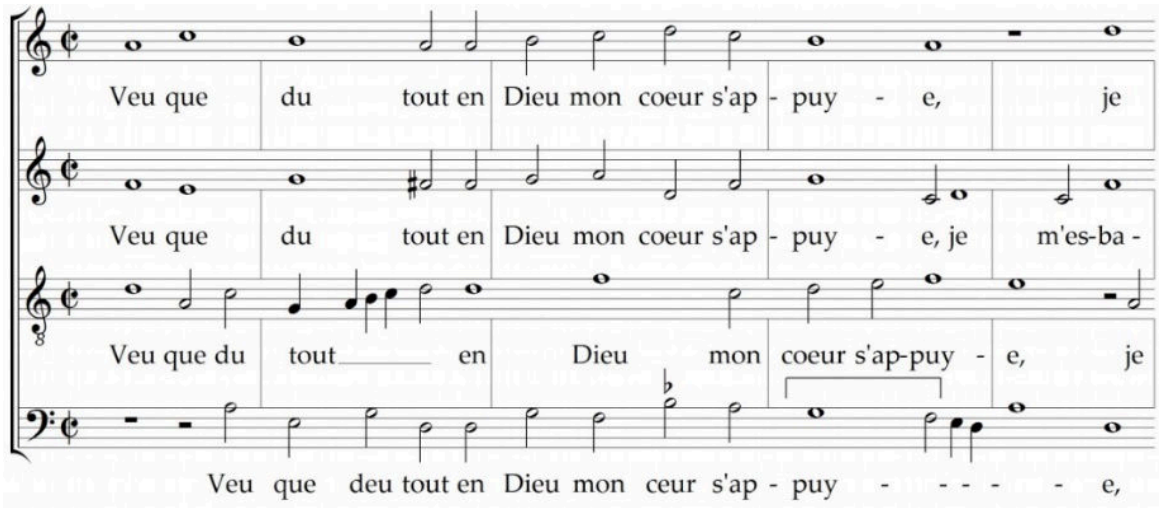

(Goudimel, 1564). 


\section{Görsel 9}

Missa, "Kyrie"

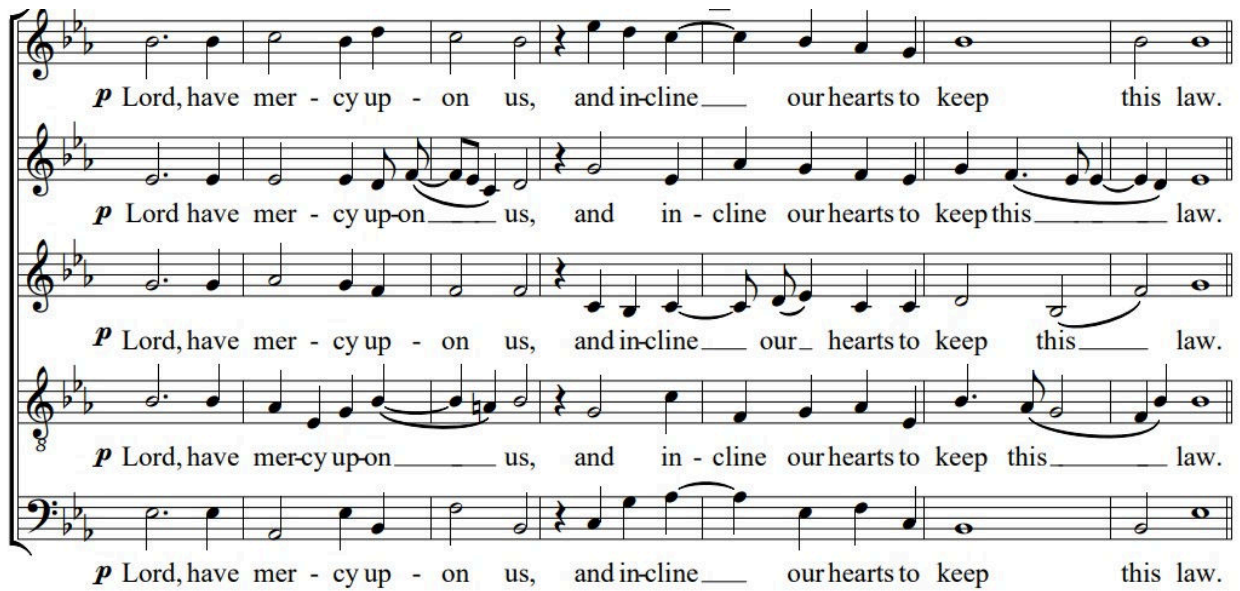

(Byrd, 1773).

“Önceleri nakaratlarla söylenen ve din dışı konuları içeren bir şarkı türü olarak ortaya çıkan Madrigal on altıncı yüzyıla yaklaştıkça aşk, taşlama, yargı ve şehvet gibi çok çeşitli dünyevi konuları işlemeye başlar. Bir münazara öncesinde veya bir diploma töreni sonrasında söylenebilen, toplumdaki sosyal olaylara kolaylıkla eşlik edebilen bir yapısı bulunmaktadır" (İlyasoğlu , 1995, s. 20).

\section{Görsel 10}

Madrigal, "Angelica Biltà"

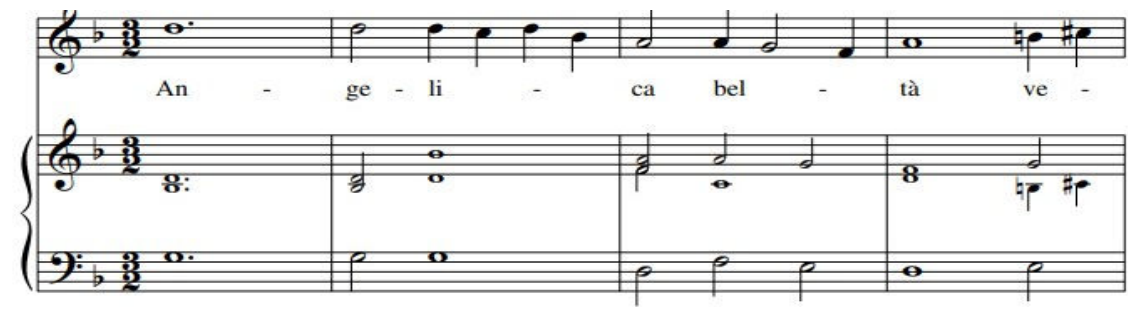

(Landini, t.y.b).

\section{Sonuç}

Orta Çă̆ boyunca din baskısı altında gelişen mimari ve plastik sanat akımlarının özellikle Gotik sanatına ve ardından gelen Rönesans dönemine etkileri incelendiğinde, 4. yüzyıldan itibaren putperestlik inancına karş1 Hristiyanlık inancını yayma amacıyla görevlendirilen din adamlarının yaptıkları çalışmaları pekiştirmek üzere göğe doğru sivrilen formlara sahip katedraller inşa edildiği, bu binaların hem dış yapısında hem de iç yapısında dini düşüncelerin hayat bulabildiği bazı tasvirler oluşturulduğu görülmüştür. Katedrallerin ana kapılarının yanında sıralanan heykellerle dini kitaplarda konu edilen olaylar canlandırılmış, Gargoyle ve Kimera isimli heykellerle de ölüm ve ölümlü insanlar tasvir edilmiştir. Kiliselerin içindeyse doğal ışığın içeri süzülerek girmesini sağlayan ve Katolik öğretiden sahneler barındıran vitraylar kullanılmış, bu dünyayla öteki dünya arasındaki bağı güçlendirmek için tavan ve duvarlara freskler çizilmiştir.

Batı Avrupa'da Hristiyanlığın en yoğun şekilde yaşandığı orta çağda, dönemin halk ezgileri derlenip dinsel içerikli sözler ilave edilerek sade bir müzikal yapıyla kiliselerde ibadet aracı olarak kullanılmıştır. Başlangıçta tek sesli, çalgı eşliği içermeyen, çok sakin karakterli ve bir oktavı aşmayan bu ezgiler sonraları Latince dilde söylenen bir bas ses üzerine özgürce seslendirilen diğer ezgilerin seslendirilmesiyle geliştirilmiştir. Daha sonraları ritmik çeşitlilikle birlikte çalgı eşliği de kullanılmaya başlanmış ve genel yapının belli kurallar çerçevesinde oluşturulması sağlanmıştır. Orta Çağ'ın sonuna gelindiğinde tek sesli ve sade yapılı ezgiler yerini özgür ritimli ve bol süslemeli ezgilere bırakmıştır.

Karanlık çağın bin yıllık totaliter yapısından uzaklaşmak isteyen toplum kendisine Yunan kültürünü örnek almak istediğinde insancıl bir düşünce hayat bulmuştur. Dünyadaki güzelliklerin farkına varan ve yaşama sevinciyle dolan toplum, yaşamı sorgularken mimaride, plastik sanatlarda ve müzikte yeni kapıları aralamıştır.

Ressamlar perspektif kurallarını geliştirdikçe kendilerini daha özgür ifade edebilme firsatı yakalamış, zanaatkar yerine sanatçı olarak tanımlanmaya başlamışlardır. Eğitimleri süresince kendilerini geometri ve anatomi 
konularında da geliştiren sanatçılar nesneleri üç boyutlu mekanlarda çizmeye başlamışlar, resimde konu edilen figürle arka plandakiler arasında mekânsal bir boşluk oluşturarak eserlere derinlik kazandırmışlardır. Tıpkı resimde olduğu gibi heykelde de insani ve dünyevi temalar seçilmiştir. Kurgu, oran, ölçü, simetri, derinlik ve hacim kavramları çerçevesinde oluşturulan insan tasvirlerinde anatomik detaylar dikkat çekmektedir.

İnsanlar bağnaz yapıya baş kaldırmak için kendilerine yeni bir mezhep oluşturdukları andan itibaren ayinlerde seslendirilen Latince sözler yerini Almancaya bırakmıştır. Baskı tekniğinin de gelişmesiyle bu yeni müzikal ibadet biçimi hızla yayılmış ve farklı ülkelerin güncel müzik yapıları diğer toplumlar tarafından da kullanılmıştır. Özgürlükler müziğe yansıtıldığında aşk, taşlama, yargı ve şehvet ve benzerleri gibi insana ait tüm duygular rahatlıkla ifade edilmeye başlanmıştır. 


\section{Kaynakça}

Akyürek, E. (1994). Ortaçă̆'dan Yeniçağ'a felsefe ve sanat. Kabalcı Yayınevi.

Animuccia, G. (1583). Motet, “A Nostri Preghi” [Şarkı notas1]. http://www0.cpdl.org/wiki/index.php/A_nostri preghi (Giovanni_Animuccia)

Anonim. (t.y.). Hecesel (syllabic) Gregorian şarkısl, “The Play of The Three Kings” [Şark1 notas1]. http://www3. cpdl.org/wiki/index.php/Officium_stellae_(Gregorian_chant)

Anonim. (t.y.). Süslemeli (melismatic) Gregorian şarkısl, “Volsvi, Persidstii Tsarie” [Şarkı notası]. http://www3.cpdl.org/wiki/index. php/Volsvi_Persidstii_tsarie_(Znamenny chant)

Apel, W. (1950). Harvard dictionary of music. Harvard University Press.

Atalay, A. (2015). Türk müziğinde komalı ses var mıdır? Ege Üniversitesi Türk Musikisi Devlet Konservatuvarı Dergisi, 7, 39-62. https://dergipark.org.tr/tr/download/article-file/751973

Boran, İ., \& Şenürkmez, K. (2015). Kültürel tarih ışığında Çoksesli Batı Müziği. Yapı Kredi Yayınları.

Brassart, J. (1445). Conductus şarkısı, “Christi Nutu Sublimato” [Şarkı notası]. http://www1.cpdl.org/wiki/index. php/Christi_nutu_sublimato_(Johannes_Brassart)

Brotton, J. (2012). Rönesans. (H. Gür, Çev.). Kültür Kitaplığı.

Buchholz, E. (2005). Leonardo da Vinci. (A. Kurultay, Çev.). Könemann.

Byrd, W. (1773). Missa, “Kyrie” [Şark1 notas1]. http://www3.cpdl.org/wiki/index.php/Kyrie (William_Byrd)

Cubberley, E. (2004). Eğitim tarihi 1. (E. Noyan, Çev.). Yeryüzü Yayınevi.

Çakır, T. (2012). Rönesans resminde mimarinin kullanılışı. (Tez No. 328713) [Yüksek Lisans Tezi, Atatürk Üniversitesi]. Yüksek Öğretim Kurulu Tez Merkezi.

Çüçen, A. (2013). Ortaçă̆ ve Rönesans'ta felsefe. Ezgi Kitabevi.

de Machaut, G. (1365). Missa, “Messe de Notre Dame” [Şarkı notas1]. http://www1.cpdl.org/wiki/index.php/ Messe_de_Nostre_Dame_(Guillaume_de_Machaut)

Elmalı, O., \& Özdem, Ö. (2013). İlkçă̆ felsefesi tarihi. Art Sanat Yayınevi.

Goudimel, C. (1564). Psalm, “Psalm 11" [Şark1 notas1]. http://www0.cpdl.org/wiki/index.php/Psalm_11 (Claude Goudimel)

İlyasoğlu , E. (1995). Zaman içinde müzik: Başlangıcından günümüze örneklerle Batı Müziğinin evrimi. Yap1 Kredi Yayınları.

Kalın, İ. (2019). Ben öteki ve ötesi Íslam-Batı ilişkileri tarihine giriş. İnsan Yayınları.

Krausse, A. (2005). Rönesanstan günümüze resim sanatının öyküsü. (D. Zapçığlu, Çev.). Tandem Verlag.

Kutlu Altan, Ö. (2015). Katolik yapıların iç mekan tasarımında Gotik ve Barok dönemin karşılaştırmalı analizi (Tez No. 436050) [Yüksek Lisans Tezi, Bahçeşehir Üniversitesi]. Yüksek Öğretim Kurulu Tez Merkezi.

Landini, F. (t.y.a). Kanon, “Cosi Pensoso” [Şark1 notas1]. http://www2.cpdl.org/wiki/index.php/Cosi_pensoso (Francesco Landini)

Landini, F. (t.y.b). Madrigal, “Angelica Biltà” [Şark1 notas1]. http://www2.cpdl.org/wiki/index.php/Angelica_bilt $\% \mathrm{C} 3 \% \mathrm{~A} 0$ (Francesco_Landini)

Nabiyeva, K. (2017). Gotik heykelcilikte Gargoyle heykeller üzerine bir araştırma (Tez No. 469049) [Yüksek Lisans Tezi, İstanbul Kültür Üniversitesi]. Yüksek Öğretim Kurulu Tez Merkezi.

Öndin, N. (2016). Rönesans düşüncesi ve resim sanatı. Hayalperest Yayınevi.

Özel, A. (2014). Estetik ve temel kuramlarl. Ütopya Yayınevi.

Pérotin. (t.y.). OrganumeEzgisi, “Alleluia: Nativitas” [Şark1 notas1]. http://www1.cpdl.org/wiki/index.php/ Organum_Alleluia_(P\%C3\%A9rotin)

Sachs, C. (1965). Kısa Dünya musikisi tarihi. (İ. Usmanbaş, Çev.). İstanbul: Milli Eğitim Basımevi.

Say, A. (2002). Müzik sözlüğ̈̈. Müzik Ansiklopedisi Yayınları.

Say, A. (2012). Müzik tarihi. Müzik Ansiklopedisi Yayınları.

Selanik, C. (1996). Müzik sanatının tarihsel serüveni. Doruk Yayımcılık. 
Sözer, V. (1986). Müzik ve müzisyenler ansiklopedisi M-Z. Remzi Kitabevi.

Şenyapı11, Ö. (2004). Rönesans. Boyut Yayıncılık.

Tufan, A. (2004). Heykelin Gotik mimarideki yeri ve önemi (Tez No. 149023) [Yüksek Lisans Tezi, Marmara Üniversitesi]. Yüksek Öğretim Kurulu Tez Merkezi.

Turan, F. (2011). Ortaçağ ve Rönesans sanatında fresk resminin yeri ve biçimsel gelişimi (Tez No. 304360) [Yüksek Lisans Tezi, Mimar Sinan Güzel Sanatlar Üniversitesi]. Yüksek Öğretim Kurulu Tez Merkezi.

Turgut, M. (2012). Tarih sanat ve siyaset yazıları: Rönesans aydınlanma ve sosyal demokrasi. Mola Kitap.

Tüzün, M. (2004). Rönesans'tan Barok'a dini ve tarihsel konulu eserlerdeki natürmort nesneleri (Tez No. 147300) [Sanatta Yeterlik Çalışması, Mimar Sinan Güzel Sanatlar Üniversitesi]. Yüksek Öğretim Kurulu Tez Merkezi.

Yıldırım, A., \& Şimşek, H. (2013). Sosyal bilimerde nitel araştırma yöntemleri. Seçkin Yayıncılık. 